\title{
The Relationship between Self-Directed Learning Skills and Science Achievement among Qatari Students
}

\author{
Ashraf Kan'an, Kamisah Osman \\ Department of Teaching and Learning Innovation, Faculty of Education, The National University of Malaysia, \\ Bangi, Malaysia \\ Email: kamisah@ukm.edu.my
}

Received 25 March 2015; accepted 18 May 2015; published 21 May 2015

Copyright (C) 2015 by authors and Scientific Research Publishing Inc.

This work is licensed under the Creative Commons Attribution International License (CC BY). http://creativecommons.org/licenses/by/4.0/

c) (i) Open Access

\begin{abstract}
This study is aimed to investigate the relationship between students' self-directed learning readiness and their science achievement. 83 students were randomly selected from a secondary school in Qatar. The students' self-directed learning readiness was measured by the Self-Directed Learning Readiness Scale (SDLRS) and their science achievement was determined by the science subject National Exam (NE) scores. The findings of the study showed that SDLRS total score significantly predicted the National Exam science subject score $(p=.049)$. It was suggested that self-directed learning is essential for students to be academically successful to their fullest potential. Therefore, attention should be given to possible causal factors of self-directed learning.
\end{abstract}

Keywords

Academic Achievement, Self-Directed Learning, Self-Directed Learning Readiness Scale

\section{Introduction}

In a rapidly changing and unstable world, many countries strive to remain competitive by updating the national education strategies (Kek \& Huijser, 2011). Hence, Qatar has initiated updates in its education system in order to remain competitive and to transform Qatar into an advanced country by 2030. In order to achieve such transformation, a world-class educational system is needed, which includes educational curricula and training programs that are appropriate to each individual's aspirations and abilities. This education system should respond to the current and future needs of the labour market and high quality educational and training requirements (General Secretariat for Development Planning, 2008). 
Science standards of the Qatari Supreme Education Council focus on preparing students to be committed and productive citizens. Critical thinking, scientific enquiry and reasoning are emphasized in these standards for all grades to ensure the development of the ability to work creatively, think analytically and solve problems effectively. In addition, the standards emphasized the significance of applied knowledge in the modern world and to the moral, ethical, social and environmental implications of science (Supreme Education Council, 2013).

Currently, schools and work settings value the importance of Self-Directed Learning (SDL) skills and it is considered as an indicator of better learning outcomes and skills that is much needed to function in the $21^{\text {st }}$ century (Murnane \& Levy, 1996). SDL is defined as "a process in which individuals take the initiative, with or without the help of others" to diagnose their learning needs, formulate learning goals, identify resources for learning, select and implement learning strategies, and evaluate learning outcomes (Knowles, 1990). According to Long (1990), SDL is the learning that occurs in one's daily life experiences. For a technologically complex and rapidly changing society, SDL is very essential for survival (Abou-Rokbah, 2002). Therefore, school students should not only have academic knowledge but also need to possess SDL skills (Areglado, Bradley \& Lane, 1996). Additionally, SDL skills enable students to determine and manage their own educational needs and not depending on their teachers (Brookfield, 1986). It is also argued that SDL exists along a continuum; it is present in each person to some degree, and students differ in their readiness for SDL (Shaikh, 2013). Hence, schools' learning activities must encourage the development of SDL skills so that it may help students to succeed in their present and future learning.

From adult education experts' perspectives, SDL consists of three dimensions: motivation, metacognition, and self-regulation (Long, 2000). Self-directed learners demonstrate, in comparison to their peers, a greater responsibility to learn and independent monitoring of their learning, thus making their learning meaningful (Garrison, 1997). They view problems as challenges, seek change, enjoy learning, inspired, determined, independent, selfdisciplined, self-confident and goal-oriented (Taylor, 1995). Self-regulated learners take on challenging tasks, practice their learning, develop a deep understanding of the learning material, and exert extra effort, which leads to academic success (Perry, Phillips, \& Hutchinson, 2006). These students self-activate and self-direct their efforts to acquire knowledge and skills by implementing specific strategies rather than just passively reacting to their teachers' instructions (Zimmerman, 1998). SDL is essential for students' transition from passive learners to active learners. Daily assignments, essays, and oral presentations become the responsibility of the students rather than being the collaborative effort of parents, teachers, and peers (Perry, Hladkyj, Pekrun, \& Pelletier, 2001).

Williamson (2007) stated that the element of self-directedness is considered essential in order for students to be academically successful to their fullest potential. Klotz (2011) conducted a correlational study to examine if there is any relationship between Self-Directed Learning Readiness (SDLR) and students' academic success. Results showed that there was no correlation between SDLRS scores and academic success. However, earlier, Hsu and Shiue (2005) conducted a study to examine how students' educational background; their SDLR and their prior success in classes affect their academic achievement differently in face-to-face and a two-way distance-learning environment. The results showed that the strength of the students' educational background (prior grade point average and SDLR) was a strong factor in determining students' academic achievement in the distance educational mode than in the face-to-face mode of learning.

Morris (1995) conducted a research on 157 randomly selected past and present students from non-traditional graduate business institution to examine the relationship between SDLR and academic achievement at the graduate level. He found a relationship between SDLR and academic achievement and the results showed that SDLRS scores were also associated with age. In addition, Darmayanti (1994) conducted a study on 272 undergraduate students at Nursing Faculty students in Chiang Mai University to investigate whether a relationship exists between SDLR and their academic progress measured by a demographic data questionnaire. Results showed a positive relationship between SDLR and academic success in traditional classroom setting. Harriman (1990) conducted a research to investigate college students' SDLR and the results were compared to achievement and completion. Results showed a significant positive relationship between SDLR and academic achievement.

Academic achievement is considered as one of the most important and classical impression about students' progress in science education. This is not only because higher achievement indicates higher technical skills that is currently in short supply, but also because higher achievement is valued in the society as an indicator of higher chance to get high-status occupations and high ability to pursue higher education (Okoye \& Okecha, 2008). In 2006, Program for International Student Assessment (PISA) of the Organisation of Economic Cooperation and Development (OECD) found that Qatar and Kyrgyzstan were among the lowest in PISA perform- 
ance (Supreme Education Council, 2013). In 2011, Trends in International Mathematics and Science Study (TIMSS) achievement test at the Grade 8 level showed that Qatar was one of the six lowest performing countries out of forty-two participating countries (Martin, Mullis, Foy, \& Stanco, 2011). The 2006, 2007, and 2008 Qatar Comprehensive Educational Assessment (QCEA) science subjects' results revealed that no science student at all grade levels met the world standards (World Data on Education, 2011). In 2010-2011 academic year, the average National Exam (NE) science subjects including Biology, Chemistry and Physics scores were 618 for $10^{\text {th }}$ grade and 648 for $11^{\text {th }}$ grade, while in 2011-2012 academic year, it was 581 for $10^{\text {th }}$ grade and 619 for $11^{\text {th }}$ grade. This clearly showed a decrease in average NE science subjects scores in the two grades (Supreme Education Council, 2013).

Given the series of flaws in the present education system in Qatar and its failure in adequately preparing Qatari students for today's challenges of technological-based society, there is a direct need to carefully and critically examine the factors influencing science achievement and interest in learning. There is a relatively little research that examined the academic trajectories of students in schools across Qatar (Areepattamannil, 2012). To date, there were no study done that examined the connection between SDLR and academic performance in science in Qatar.

Therefore, in order to attempt a solution to the said problems, a study was conducted to investigate if there is any relationship between academic achievement in science and Self-Directed Learning Readiness (SDLR) among Qatari students. Some of the research questions to be answered are: (1) Is there any relationship between SDLR and academic achievement in science among students? (2) Is there any difference between students' SDLR based on nationality (Qatari and non-Qatari)? (3) Is there any difference between students' SDLR based on their grade level $\left(10^{\text {th }}\right.$ and $\left.11^{\text {th }}\right)$ ? and (4) Is there any correlation between students' SDLR and their ages?

This study is expected to make a positive contribution for Qatar's educational system in general and secondary independent schools in particular. The survey on the possibilities of SDLR as a contributing factor towards higher academic achievement in science may highlight the needs for students to instil SDL skills in themselves to be academically successful in science subjects, and for teachers to embed the components of SDL skills in the classroom. In addition, it may help the Qatar education system to prepare students to enter higher education institutions and provide information about students' SDLR to Qatari universities, where the SDLRS results may identify students who are not initially ready for the rigors of academia and enable educational institutions to position them for academic success. This study will also open doors for future researchers to measure students' SDLR of different grades, schools and genders in Qatar.

\section{Research Methodology}

\subsection{Research Design}

This study used a cross-sectional survey design to determine the relationship between Self-directed Learning Readiness (SDLR) and academic achievement in science. Survey design was employed in this study due to its ability to describe the issues faced and its ability to be generalized to the population with accuracy and effectiveness as the size of the sample used in the survey was large enough (Creswell, 2013).

\subsection{Research Sample}

The samples of this study, randomly selected, were $8310^{\text {th }}$ and $11^{\text {th }}$ grade students from Nasser Bin Abdullah Al-Atyyia (NBA) Independent School for boys in Qatar that comprised of 44 students from $10^{\text {th }}$ grade and 39 students from $11^{\text {th }}$ grade and also consist of 21 non-Qatari and 62 Qatari students, from a population of 271 students. The ratio of selected students exceeded $30 \%$ of the total students (Neuman \& Kreuger, 2003).

\subsection{Instrument and Procedures}

\subsubsection{Self-Directed Learning Readiness Scale (SDLRS)}

The Self-Directed Learning Readiness Scale (SDLRS) developed by Guglielmino (1989) were utilized to measure students' self-directed learning readiness (SDLR). The SDLRS is a self-reported instrument comprised of 58-items to measure students' SDLR. Each item has a 5-point Likert scale with the description " $1=$ almost never true of me", " 2 = usually not true of me", " 3 = sometimes true of me", " 4 = usually true of me", " $5=$ almost always true of me". The summation of all 58 items scores would equal the total score on the SDLRS. The 
scale contains 41 positively stated items and 17 negatively stated items, which were used as a mean of avoiding participant to answer similarly (Guglielmino, 1989). The overall SDLRS score would be used to represent the students' SDLR instead of the subscores derived from SDLRS factors due to its excellent reliability index and interpretability.

The validity and reliability of SDLRS were supported by several studies. According to Guglielmino (2008), the SDLRS was assessed by Finestone (1984) and Wiley (1981) for test-retest reliability and achieved high test-retest reliability scores of 0.82 (Finestone, 1984) and 0.79 (Wiley, 1981). The SDLRS was also found to have alpha reliability reading above the minimum of 0.70 for all the subscales in the instrument (Boden, 2005). This showed that the SDLRS has a high reliability. In addition, the SDLRS was found to have significant correlation with levels of SDL (Finestone, 1984; Skaggs, 1981), preference for challenge, curiosity for learning, and perceived scholastic competence (Posner, 1989). This showed that the SDLRS has a high validity to measure participants' SDL.

In this study, the instrument was piloted and split-half and odd-even reliability was computed. The coefficient, corrected by the Spearman-Brown method was 0.92 , which suggests high reliability for the Arabic version of the SDLRS.

\subsubsection{National Exam (NE) Science Subjects Accumulated Score}

In the Qatari educational reform, the Evaluation Institute is responsible for monitoring students and independent schools' academic performance by designing and administering National Exam (NE) in the four subjects, which are Arabic Language, English Language, Mathematics and Science. The National Exam (NE) is under the supervision of the Qatar Supreme Education Council and a part of Qatar Comprehensive Educational Assessment (QCEA). The NE was established concerning the Qatar Curriculum Standards, which evaluation was based on demanding educational standards and high goals (Supreme Education Council, 2013).

For the purpose of this study, the participants' accumulated scores in the subjects of Biology, Physics and Chemistry in the NE that were conducted at the end of the second semester of 2012/2013 academic year were obtained.

\subsection{Data Analysis}

Simple linear regression was used to determine if SDLRS scores have any influence on the NE science subjects scores. Independent t-test was used to compare continuous variable between two groups, where chi-square test were used to compare the ration between two groups. Finally, Pearson correlation was used to test the correlation between SDLRS scores and age of participants. Significance level was set at .05 for all tests.

\section{Research Findings}

Table 1 shows the NE science subjects' scores and SDLRS scores of the students. From the results, it was found that the mean for NE science subjects' scores was 40.42 and the standard deviation was 18.10 while the mean for SDLRS scores was 197.45 and the standard deviation was 16.14 .

Table 2 shows the correlation between SDLRS total scores and NE science subjects scores. From the results, there was a significant positive correlation between SDLRS total score and the NE science subjects scores $(p$ $=.049, \mathrm{r}=.218$ ).

Table 3 shows the linear regression analysis of SDLRS as a predictor of NE science subjects scores. From the results, it was found that the SDLRS total score significantly predicted the NE science subjects score $(p=.049)$. For every one score increase in SDLRS score, the NE science subjects score was expected to increase by 244 times $(95 \% \mathrm{CI}=.001-.488)$. The SDLRS could explain approximately $4.7 \%$ of the variation in NE science subjects score.

Table 1. Students' NE science subjects scores and SDLRS scores.

\begin{tabular}{cccc}
\hline & Number of students & Mean & Standard deviation \\
\hline NE Science Subjects Score (100\%) & 83 & 40.42 & 18.10 \\
SDLRS Total Score & 83 & 197.45 & 16.14 \\
\hline
\end{tabular}


Table 4 shows the SDLRS scores of the students based on nationality, grades, and age. From the results, it was found that the mean for SDLRS scores for Qatari students was 196.68 and the standard deviation was 18.33 while the mean for non-Qatari students was 196.67 and the standard deviation was 15.33. Also, the mean for SDLRS scores for 10th grade students was 198.16 and the standard deviation was 16.56 while the mean for 11 th grade students was 195.00 and the standard deviation was 18.64. And, the mean for SDLRS scores for $15-16$ years old students was 199.71 and the standard deviation was 16.28 while the mean for 16 - 17 years old students was 195.19 and the standard deviation was 18.38 .

T-test of SDLRS Total Scores based on nationality showed that there were no significant differences of SDLRS total scores between Qatari and non-Qatari students $(p=.998)$. The mean of the Qatari students' scores was $196.68( \pm 18.33)$, while the mean of non-Qatari students' scores was $196.67( \pm 15.33)$. T-test of SDLRS Total Scores based on grade level shows that there were no significant difference of SDLRS total scores between 10 th and 11 th grade students $(p=.42)$. The mean of the 10th grade students' scores was 198.16 $( \pm 16.56)$, while the mean of 11 th grade students' scores was $195.00( \pm 18.64)$. Correlation between students' age and SDLRS total score shows that there was no significant relationship between the SDLRS total score and students' age ( $\mathrm{r}=$ $-.09, p=.42)$.

\section{Discussion}

This study demonstrated a significant relationship between $10^{\text {th }}$ and $11^{\text {th }}$ grade students' SDLR and their academic achievement in science as measured by Qatari NE science subjects, and the SDRLS total score significantly predicted their science academic achievement. These findings were parallel to the conclusions of Hsu and Shiue (2005), Morris (1995), Darmayanti (1994) and Harriman (1990). From the results, it can be concluded that students that are highly self-directed can depend on themselves in learning science and would have greater academic achievement in science. In order to incorporate suitable teaching strategies to match the student's needs, schools should not only diagnose their students' (especially new students) ability and the factors that are associated with academic achievement in science, but also their SDLR that can be used as a classification variable.

Table 2. Correlation between SDLRS total score and NE science subjects score.

\begin{tabular}{|c|c|c|}
\hline & & SDLRS Total Score \\
\hline \multirow{3}{*}{ NE Science Subjects Score (100\%) } & Pearson Correlation & .218 \\
\hline & Sig. (2-tailed) & .049 \\
\hline & $\mathrm{N}$ & 83 \\
\hline
\end{tabular}

Table 3. Regression analysis of SDLRS as a predictor of NE science subjects score.

\begin{tabular}{ccccc}
\hline Predictor & B $(95 \%$ CI $)$ & Std. E & R square & 24.25 \\
Constant & $-7.811(40.45$ to -56.08$)$ & .748 \\
SDLRS total score & $.24(.49$ to .001$)$ & .12 & .047 \\
\hline
\end{tabular}

Table 4. Students' SDLRS Total Scores Based on Nationality, Grades, and Age.

\begin{tabular}{|c|c|c|c|c|}
\hline & & Number of students & SDLRS Mean & Std. Deviation \\
\hline \multirow[t]{2}{*}{ Nationality } & Qatari & 62 & 196.68 & 18.33 \\
\hline & Non-Qatari & 21 & 196.67 & 15.33 \\
\hline \multirow[t]{2}{*}{ Grades } & $10^{\text {th }}$ grade & 44 & 198.16 & 16.56 \\
\hline & $11^{\text {th }}$ grade & 39 & 195.00 & 18.64 \\
\hline \multirow[t]{2}{*}{ Age } & $15-16$ years & 41 & 199.71 & 16.28 \\
\hline & $16-17$ years & 42 & 195.19 & 18.38 \\
\hline
\end{tabular}


The students' SDLR can also act as a predictor of students' success; hence, it would be useful to the instructor and school managers in supporting students at their appropriate levels.

In addition, the study has found no significant relationship between SDLRS total score and the students' age, which ranged from 15 to 17 years old. It was suggested that SDL is a personal trait that increases with age (Lounsbury, Levy, Park, Gibson, \& Smith, 2009), and that personality traits would naturally increase until late adolescence (Arnett, 1999; McCrae et al., 2002). However, there was no significant relationship between SDLR and age demonstrated in this study. The insignificance of the relationship may be due to the age range being too small. A larger age range might be needed in order to exhibit the relationship between the two variables.

The findings also show no significant difference in SDLRS total score based on grade level. Lounsbury et al. (2009) suggested that a higher SDLRS score in higher grade levels could be attributed to a higher opportunity for SDL in higher grade levels due to increased environmental resources for SDL such as computers with Internet connections, or function of instructional design. However, in the NBA school, the $10^{\text {th }}$ and $11^{\text {th }}$ grade students have the same environmental resources and learned using the same instructional strategies. Therefore, this explains the insignificance in the differences in SDLRS total score based on grade level.

The general population in NBA school is made up of $74.7 \%$ Qatari students and $24.3 \%$ of non-Qatari students of other nationalities such as Egyptian, Palestinian, Jordanian and others. The results indicated that there was no significant difference in SDLRS total score based on the students' nationality. This was because despite the students being of different races, they have the same religion, culture, language, local area and educational backgrounds. Therefore, there were little differences in their personality and culture.

These findings showed that the SDLRS could be used by school academics as a diagnostic survey to indicate the students' SDL levels. The knowledge can be utilized to prepare suitable programs to support these different levels, which may progress the school academic achievement and prepare the students to enter university, where SDL skills and autonomy are much needed. The results of this study would add to the growing body of researches on factors predicting academic success in science among school students.

\section{Conclusion}

This study examined the relationship between Self-Directed Learning Readiness (SDLR) and science academic achievement among $10^{\text {th }}$ and $11^{\text {th }}$ grade students. This study claimed that a significant relationship exists between SDLR and science academic achievement, and that SDLR significantly predicted science academic achievement, while there were no significant differences in SDLR between races, nationality and age. Therefore, SDLR was suggested to be one of the contributing factors towards higher academic achievement in science. Hence, embedding the components of SDL in teaching and encouraging the development of SDL skills among students might be beneficial and rewarding for the students to be academically successful in not only science subjects, but also other subjects as well as to be successful in the business of life.

Future research is recommended to measure SDLR in other Qatar schools with different genders and grades. These data will help the decision makers and academicians in the Supreme Education Council in designing and planning courses that integrate SDL in the school curriculums and teaching strategies.

\section{References}

Abou-Rokbah, E. H. (2002). Readiness for Self-Directed Learning in Saudi Arabian Students. Doctoral Dissertation, St. Louis: University of Missouri.

Areepattamannil, S. (2012). Effects of Inquiry-Based Science Instruction on Science Achievement and Interest in Science: Evidence from Qatar. The Journal of Educational Research, 105, 134-146.

http://dx.doi.org/10.1080/00220671.2010.533717

Areglado, R. J., Bradley, R. C., \& Lane, P. S. (1996). Learning for Life: Creating Classrooms for Self-Directed Learning. Thousand Oaks, CA: Corwin Press, Inc.

Arnett, J. J. (1999). Adolescent Storm and Stress, Reconsidered. American Psychologist, 54, 317. http://dx.doi.org/10.1037/0003-066X.54.5.317

Boden, C. (2005). An Exploratory Study of the Relationship between Epistemology Beliefs and Self-Directed Learning Readiness. Doctoral Dissertation, Kansas, Manhattan: Kansas State University.

Brookfield, S. D. (1986). Understanding and Facilitating Adult Learning: A Comprehensive Analysis of Principles of Effective Practices. San Francisco, CA: Jossey-Bass. 
Creswell, J. W. (2013). Research Design: Qualitative, Quantitative, and Mixed Methods Approaches. New York: Sage.

Darmayanti, T. (1994). Readiness for Self-Directed Learning and Achievement of the Students of Universitas Terbuka (The Indonesian Open Learning University). Master Thesis, Greater Victoria, BC: The University of Victoria.

Finestone, P. (1984). A Construct Validation of the Self-Directed Learning Readiness Scale with Labour Education Participants. Doctoral Dissertation, Canada: University of Toronto.

Garrison, D. R. (1997). Self-Directed Learning: Toward a Comprehensive Model. Adult Education Quarterly, 48, 18-33. http://dx.doi.org/10.1177/074171369704800103

General Secretariat for Development Planning (2008). Qatar National Vision 2030. http://www.gsdp.gov.qa/www1_docs/QNV2030_English_v2.pdf

Guglielmino, L. (1989). Reactions to Field's Investigation into the SDLRS: Guglielmino Responds to Field's Investigation. Adult Education Quarterly, 39, 235-240. http://dx.doi.org/10.1177/0001848189039004005

Guglielmino, L. M. (2008). Why Self-Directed Learning. International Journal of Self-Directed Learning, 5, 1-14.

Harriman, J. K. (1990). The Relationship between Self-Directed Learning Readiness, Completion and Achievement in a Community College Telecourse Program. Doctoral Dissertation, Athens, GA: University of Georgia.

Hsu, Y. C., \& Shiue, Y. M. (2005). The Effect of Self-Directed Learning Readiness on Achievement Comparing Face-toFace and Two-Way Distance Learning Instruction. International Journal of Instructional Media, 32, 143-155.

Kek, M., \& Huijser, H. (2011). Exploring the Combined Relationships of Student and Teacher Factors on Learning Approaches and Self-Directed Learning Readiness at a Malaysian University. Studies in Higher Education, 36, 185-208. http://dx.doi.org/10.1080/03075070903519210

Klotz, J. C. (2011). An Examination of the Relationship between Self-Directed Learning Readiness and Academic Achievement in First Semester College Students. Doctoral Dissertation, Minneapolis, MN: Capella University.

Knowles, M. S. (1990). The Adult Learner: A Neglected Species. Houston, TX: Gulf Publishing Co.

Long, H. B. (1990). College Students' Self-Directed Learning Readiness and Educational Achievement. In H. B. Long, \& Associates (Eds.), Self-Directed Learning: Consensus and Conflict (pp. 107-122). Norman, OK: Oklahoma Research Centre for Continuing Professional and Higher Education.

Long, H. B. (2000). Understanding Self-Direction in Learning. In H. B. Long (Ed.), Practice \& Theory in Self-Directed Learning (pp. 11-24). Schaumburg, IL: Motorola University Press.

Lounsbury, J. W., Levy, J. J., Park, S. H., Gibson, L. W., \& Smith, R. (2009). An Investigation of the Construct Validity of the Personality Trait of Self-Directed Learning. Learning and Individual Differences, 19, 411-418. http://dx.doi.org/10.1016/j.lindif.2009.03.001

Martin, M. O., Mullis, I. V. S., Foy, P., \& Stanco, G. M. (2011). TIMSS 2011 International Results in Science. http://timssandpirls.bc.edu/timss2011/downloads/T11_IR_Science_FullBook.pdf

McCrae, R. R., Costa Jr., P. T., Terracciano, A., Parker, W. D., Mills, C. J., De Fruyt, F., \& Mervielde, I. (2002). Personality Trait Development from Age 12 to Age 18: Longitudinal, Cross-Sectional and Cross-Cultural Analyses. Journal of Personality and Social Psychology, 83, 1456-1468. http://dx.doi.org/10.1037/0022-3514.83.6.1456

Morris, S. S. (1995). The Relationship between Self-Directed Learning Readiness and Academic Performance in a NonTraditional Higher Education Program. Doctoral Dissertation, Norman, OK: University of Oklahoma.

Murnane, R. J., \& Levy, F. (1996). Teaching the New Basic Skills: Principles for Educating Children to Thrive in a Changing Economy. New York: Free Press.

Neuman, W. L., \& Kreuger, L. (2003). Social Work Research Methods: Qualitative and Quantitative Approaches. Boston, MA: Allyn and Bacon.

Okoye, N. S., \& Okecha, R. E. (2008). The Interaction of Logical Reasoning Ability and Socio-Economic Status on Achievement in Genetics among Secondary School Students in Nigeria. College Student Journal, 42, 617-624.

Perry, N. E., Phillips, L., \& Hutchinson, L. (2006). Mentoring Student Teachers to Support Self-Regulated Learning. The Elementary School Journal, 106, 237-254. http://dx.doi.org/10.1086/501485

Perry, R. P., Hladkyj, S., Pekrun, R. H., \& Pelletier, S. T. (2001). Academic Control and Action Control in the Achievement of College Students: A Longitudinal Field Study. Journal of Educational Psychology, 93, 776-789.

http://dx.doi.org/10.1037/0022-0663.93.4.776

Posner, F. G. (1989). A Study of Self-Directed Learning, Perceived Competence and Personal Orientation among Students in an Open Alternative High School. Doctoral Dissertation, Denver, CO: University of Denver.

Shaikh, R. B. (2013). Comparison of Readiness for Self-Directed Learning in Students Experiencing Two Different Curricula in One Medical School. Gulf Medical Journal, 2, 27-31. 
Skaggs, B. J. (1981). The Relationships between Involvement of Professional Nurses in Self-Directed Learning Activities, Loci of Control, and Readiness for Self-Directed Learning Measures. Doctoral Dissertation, Austin, TX: University of Texas.

Supreme Education Council (2013). Education for a New Era. http://www.sec.gov.qa/En/SECInstitutes/EducationInstitute/Offices/Pages/ScienceStandards.aspx

Taylor, B. (1995). Self-Directed Learning: Revisiting an Idea Most Appropriate for Middle School Students. http://files.eric.ed.gov/fulltext/ED395287.pdf

Wiley, K. (1981). Effects of a Self-Directed Learning Project and Preference for Structure on Self-Directed Learning Readiness of Baccalaureate Nursing Students. Doctoral Dissertation, DeKalb, IL: Northern Illinois University.

Williamson, S. N. (2007). Development of a Self-Rating Scale of Self-Directed Learning. Nurse Researcher, 14, 66-83. http://dx.doi.org/10.7748/nr2007.01.14.2.66.c6022

World Data on Education (2011). Russian Federation. http://www.ibe.unesco.org/fileadmin/user_upload/Publications/WDE/2010/pdf-versions/Russian_Federation.pdf

Zimmerman, B. J. (1998). Academic Studying and the Development of Personal Skill: A Self-Regulatory Perspective. Educational Psychologist, 33, 73-86. http://dx.doi.org/10.1080/00461520.1998.9653292 